\title{
EMPIRICAL STUDY REGARDING LONG-TERM VERSUS SHORT-TERM ORIENTATION IN ROMANIA
}

\author{
Edit LUKÁCS ${ }^{a *}$, Daniel LOVIN ${ }^{b}$, Robert STEFAN ${ }^{c}$ \\ a , b, c „,Dunărea de Jos” University of Galati, Romania
}

DOI: $10.24818 / \mathrm{IMC} / 2020 / 04.18$

\begin{abstract}
Thanks to globalization and the information age, respectively to the increasing interconnectivity of the world, the cultural diversity of humankind is revealing itself evermore, contacts among individuals belonging to a variety of cultures being more and more frequent. Thus, the need arises to understand the way people think and behave. Culture influences people's thought processes and behaviour, which reflect into every aspect of life. Cultural differences can be explained by means of the cultural dimensions developed by Geert Hofstede in his works, one of these dimensions being long-term orientation. Long-term orientation has been associated with economic growth. Based on an empirical research, our study aims to highlight which of the cultural values associated with long-term and short-term orientation are predominant in Romanian culture. The results show an intermediate score of 53, close to Hofstede's estimates (52), on a scale from 0 to 100 between shortterm orientation and long-term orientation. Following the Chi square statistical test, we found a positive correlation between the respondents' level of education and the preferences for the values associated with the long-term orientation.
\end{abstract}

KEYWORDS: cultural values, Hofstede cultural model, long-term orientation, short-term orientation.

\section{INTRODUCTION}

Knowledge of the cultural values of a society, of specific patterns of thinking, is especially important for a deeper understanding of social behaviors and how society's institutions (family, education, economy, etc.) function and fulfill their own goals. No part of our lives is exempt from the influence of culture. Culture influences the way we live, the way we are raised, the way we lead and are led, but also the theories we are able to develop to explain our practices.

For four decades, since the publication in 1980 of Geert Hofstede's work entitled "The Consequences of Culture", the model of culture proposed by the Dutch specialist, as collective mental programming, has been around the world, enjoying wide acceptability and providing the starting point for a great deal of intercultural research work. The six cultural dimensions identified by Hofstede (power distance, individualism-collectivism, masculinity-femininity, avoidance of uncertainty, long-term orientation and indulgence-austerity) shed more light on understanding the differences that occur in family relationships, at school, in society, in relations with authority, in the face of future unknowns, in the way we perceive well-being, but also in other aspects, such as the correlation of cultural values with economic growth.

The long-term versus short-term orientation was introduced by Hofstede in his model after 1991, following the Chinese Values Survey, which highlighted other values not seen in his previous

\footnotetext{
* Corresponding author. E-mail address: elukacs2013@gmail.com
} 
surveys. Initially, the dimension was called Confucian dynamism, because in its components the teachings of Confucius were recognized.

Long-term orientation (LTO) is the cultivation of future-oriented virtues, especially perseverance, temperance, and a sense of shame. On the other hand, short-term orientation is the cultivation of virtues related to the past and present, especially respect for tradition, defending one from "losing face" and fulfilling social obligations (Hofstede et al., 2012). If in a long-term oriented society a person is considered to have superior abilities if they adapt to new challenges, in short-term oriented societies the persons considered to have superior abilities are the ones who are always the same, in any situation (Hofstede, et al., 2012). Long-term-oriented nations seek to learn from other countries, while short-term-oriented nations are proud of everything that has to do with their own country.

Differences in long-term orientation have many consequences for business. The values on the positive side of LTO, such as perseverance, temperance, prioritization of relationships according to status and the feeling of shame support entrepreneurial activity. Perseverance in pursuing a goal is an essential trait for an entrepreneur at the beginning of the road. Temperance brings with it savings and capital that can be reinvested. Accepting unequal relationships and a harmonious, stable hierarchy and complementarity of roles facilitates the mission of the entrepreneur. And the value of the feeling of shame encourages the establishment of connections by means of the attention paid to social interactions and emphasizes fulfillment of obligations. Adversely, short-term orientation implies personal security and stability. These two characteristics, if overestimated, discourage initiative, taking the risks associated with research and the flexibility to make decisions. In addition, too much respect for traditions hinders innovation.

Futurologist Hermann Kahn formulated a neo-Confucian hypothesis that the economic success of the East Asian countries in the last decades could be attributed to the common Confucian values inherited from history, which were a competitive advantage for success in economic activities (Kahn, 1979). Kahn's hypothesis was demonstrated by the Hofstede Survey of Chinese Values.

In this paper we have proposed an empirical research on the values associated with the long-term orientation of Romanians, having as objectives: (1) calculating a general score for the OTL dimension, (2) testing the existence of a correlation between the respondents' level of education and their income level and the long-term versus short-term orientation, (3) interpretation of answers to questions.

\section{PREVIOUS RESEARCH}

A study conducted by the consultancy agency Interact in 2005, on Romanian values and behavior from the perspective of the Hofstede cultural model, concluded that, in Romania, the short-term orientation (with a recorded score of 41) is at the cause of the low level of capital reinvestment and the need to get rich quickly.

Studies in recent years reconfirm that, in Romania, culture continues to be characterized by a low value of this dimension.

In the research paper entitled "Cultural dimensions in Romanian management", published in 2006, the university professor $\mathrm{PhD}$. Ioan Mihut, together with the university lecturer $\mathrm{PhD}$. Dan Lungescu diverge from Hofstede's methodology by elaborating a completely different questionnaire in form, but through which they followed the elements found by him to be fundamental for the cultural dimensions of his theory. In spite of the different approach, the study's results were convergent with those estimated by Hofstede for the Romanian culture, thus reconfirming the validity of the Dutch psychosociologist's theory. Regarding the dimension of long-term orientation, the survey conducted by Mihut and Lungescu asked 4 questions: (1) How do you spend most of your free time?, (2) What do you think about the assimilation of foreign holidays (Halloween, Valentine's Day, etc.) in Romania?, (3) You are a manager. How do you handle small, routine activities? and (4) If you won a few billion lei in a lottery, what would you do with most of that money? Although, in the case of 
the first question, the validity of the result (average LTO value) was affected by the fact that the students (comprising a large part of the sample) were not clear with or ignored the fact that the answer referring to „study activities” was tied exclusively to free time (extra-curricular study), not to the time dedicated to intra-curricular study, the overall result based on the 4 questions indicated an average level of long-term orientation in Romania. The authors of the study conclude that this average value results from the confluence of traditionalism that still exists at the deep levels of Romanian culture with the ease with which changes manifest at its surface level.

In the scientific paper entitled "Cultural Dimensions in Romanian Management" the authors S. Rusu, F. Isac and R. Curteanu (2015), from the Aurel Vlaicu University of Arad, analyze the impact of Romanian cultural dimensions on the style of Romanian management, discovering the issues that appear as a consequence: difficulties in planning, lack of innovation, increasing instability. The study finds that, among Romanians, short-term orientation is predominant, respectively the fact that their vision is oriented towards the past and present, to the detriment of long-term vision. This is reflected in indicators such as low level of savings, dependency on loans and propensity to consume. The authors of the paper also refer to the study of academic PhD. Dorin Bodea from 2013, in which he finds that the cultural feature of short-term orientation of Romanians (very focused on the present), along with their materialistic and egocentric character leads to a conflict between the „self” and “others”, a struggle in which money and power make the rules. "The central values (of Romanians) strongly express the present, seizing the moment, a type of personal happiness resulting especially from money, power, fame, and the recognition by others" - says Dorin Bodea in the paper Values of Romanian employees (Bodea 2012).

An article signed by Gănescu, Gangone and Asandei (2014) analyzes the national cultural system, through the lens of the cultural dimensions of Geert Hofstede and consumer-savvy responsible organizational behavior. According to the study, the link between responsible organizational behavior and the dimension of long-term versus short-term orientation is as follows: „Organizations operating in cultures with a high level of LTO are rapidly adapting to consumer expectations, making more efficient use of available resources and behaving more responsibly towards consumers. Those operating in short-term oriented cultures find it difficult to identify long-term strategies and policies that contribute to improving communication with consumers and choose to rather assess past or present results, without drafting future forecasts and plans. In the ranking of European Union countries, achieved by the authors of the research, based on the index of consumerresponsible organizational behavior, Romania has a below-average position, indicating that responsibility towards consumers is not a priority.

In November 2019, a research team from the Center for Scientific Research in Psychology, of the Republic of Moldova, published the paper entitled "Cultural and Psychological Analysis of Society in the Republic of Moldova", using the theoretical model of Geert Hofstede (Popov et al., 2020; Luca, 2016). The study obtained a score of 36 points for the cultural dimension of long-term orientation in Moldova, which places the country as more short-term oriented than Romania, which, according to Geert Hofstede's estimates, has a score of 52 points. Some characteristics, principles or realities that the authors of the study find of the Moldovan people and state, as a consequence of the predominant short-term orientation and which are similar to those valid in Romania, are: expecting efforts to correlate with rapid results, slow economic growth, valuing short-term profits, the opposition between managers and subordinates, national pride, success and failure attributed to luck, the appeal to popular wisdom, mysticism and witchcraft, the view of old age as an unhappy time, animosity towards living with in-laws and so on. 


\section{RESEARCH METHODOLOGY}

Starting from the definition of the long-term versus short-term orientation dimension, from Hofstede's cultural model, and the values associated with the two poles, we created a questionnaire, which in addition to the questions concerning the demographics of the respondents (gender, place of origin, level of studies, income level and field of activity), asked 21 questions, meant to highlight which of the two poles of the cultural dimension analyzed Romanians are biased towards. The questionnaire was distributed online and participants were asked to express their agreement with it. A Likert scale was attached to the items of the questionnaire, where $1=$ total agreement, $5=$ total disagreement. Our sample included 545 respondents from several counties: Galați, Brăila, Tulcea, Vrancea, Iași, Neamț, Bacău, Bihor, Ilfov, Brașov, Sibiu, Sălaj, but there were also respondents from the diaspora. Although our survey did not cover all the counties nationwide, due to the relatively large number of respondents, the sample is representative, especially for the region of Moldova, where most of the answers came from. The questions comprising the questionnaire and the distribution of the answers are laid out in Table 1, and the structure of the sample according to gender, level of education, type of organization and level of income is found in figures 1, 2, 3 and 4.

Table 1. The questionnaire and the distribution of answers

\begin{tabular}{|l|c|c|c|c|c|c|}
\cline { 2 - 7 } & $\begin{array}{l}\text { Strongly } \\
\text { disagree }\end{array}$ & Disagree & Neutral & Agree & $\begin{array}{c}\text { Strongly } \\
\text { agree }\end{array}$ & $\begin{array}{c}\text { Mean } \\
\text { score }\end{array}$ \\
\hline Questions & $\mathbf{5}$ & $\mathbf{4}$ & $\mathbf{3}$ & $\mathbf{2}$ & $\mathbf{1}$ & \\
\hline $\begin{array}{l}\text { 1. I save money } \\
\text { regularly in case of } \\
\text { emergencies or for } \\
\text { future. }\end{array}$ & $\mathbf{1 6}$ & $\mathbf{3 7}$ & $\mathbf{1 2 4}$ & $\mathbf{1 7 7}$ & $\mathbf{1 9 1}$ & $\mathbf{2 . 1 0}$ \\
\hline $\begin{array}{l}\text { 2. I find opportunities } \\
\text { to invest for the future. }\end{array}$ & $\mathbf{2 8}$ & $\mathbf{4 9}$ & $\mathbf{1 3 1}$ & $\mathbf{1 6 0}$ & $\mathbf{1 7 7}$ & $\mathbf{2 . 2 4}$ \\
\hline $\begin{array}{l}\text { 3. I think having a } \\
\text { sense of shame is } \\
\text { important. }\end{array}$ & $\mathbf{1 0}$ & $\mathbf{2 4}$ & $\mathbf{8 2}$ & $\mathbf{1 3 5}$ & $\mathbf{2 9 3}$ & $\mathbf{1 . 7 5}$ \\
\hline $\begin{array}{l}\text { 4. Status and rank are } \\
\text { important. }\end{array}$ & 8 & 16 & 131 & 206 & 184 & 2.00 \\
\hline $\begin{array}{l}\text { 5. Reciprocity of } \\
\text { greeting favors and gifts } \\
\text { are important. }\end{array}$ & 12 & 15 & 102 & 174 & 242 & 1.86 \\
\hline $\begin{array}{l}\text { 6. Protecting one's face } \\
\text { is important. }\end{array}$ & 25 & 50 & 171 & 178 & 121 & 2.41 \\
\hline $\begin{array}{l}\text { 7. Personal stability is } \\
\text { important. }\end{array}$ & 1 & 4 & 29 & 98 & 410 & 1.31 \\
\hline $\begin{array}{l}\text { 8. Respect for tradition } \\
\text { is important. }\end{array}$ & 16 & 47 & 144 & 181 & 156 & 1.93 \\
\hline $\begin{array}{l}\text { 9. I have long term } \\
\text { objectives. }\end{array}$ & $\mathbf{7}$ & $\mathbf{1 1}$ & $\mathbf{9 0}$ & $\mathbf{1 7 0}$ & $\mathbf{2 6 7}$ & $\mathbf{1 . 7 5}$ \\
\hline $\begin{array}{l}\text { 10. Family heritage is } \\
\text { important. }\end{array}$ & 20 & 53 & 135 & 159 & 177 & 1.90 \\
\hline $\begin{array}{l}\text { 11. I value a strong link } \\
\text { to my past. }\end{array}$ & 35 & 92 & 172 & 137 & 109 & 2.64 \\
\hline $\begin{array}{l}\text { 12. I work hard for } \\
\text { success in the future. }\end{array}$ & $\mathbf{4}$ & $\mathbf{1 2}$ & $\mathbf{8 5}$ & $\mathbf{1 6 9}$ & $\mathbf{2 7 5}$ & $\mathbf{1 . 7 1}$ \\
\hline
\end{tabular}




\begin{tabular}{|c|c|c|c|c|c|c|}
\hline & $\begin{array}{l}\text { Strongly } \\
\text { disagree }\end{array}$ & Disagree & Neutral & Agree & $\begin{array}{c}\text { Strongly } \\
\text { agree }\end{array}$ & $\begin{array}{l}\text { Mean } \\
\text { score }\end{array}$ \\
\hline $\begin{array}{l}\text { 13. I don't mind giving } \\
\text { up today's fun for } \\
\text { success five years from } \\
\text { now. }\end{array}$ & 15 & 21 & 130 & 168 & 210 & 2.01 \\
\hline $\begin{array}{l}\text { 14. Persistence is } \\
\text { important to me. }\end{array}$ & 2 & 8 & 86 & 213 & 236 & 1.76 \\
\hline $\begin{array}{l}\text { 15. If there is something } \\
\text { expensive i really want } \\
\text { but do not have money, I } \\
\text { will buy it anyway. }\end{array}$ & 170 & 148 & 132 & 65 & 30 & 3.66 \\
\hline $\begin{array}{l}\text { 16. I plan for the long } \\
\text { term. }\end{array}$ & 5 & 42 & 147 & 211 & 136 & 2.20 \\
\hline $\begin{array}{l}\text { 17. Traditional values } \\
\text { are important to me. }\end{array}$ & 17 & 49 & 165 & 178 & 133 & 2.33 \\
\hline $\begin{array}{l}\text { 18. I prefer to know } \\
\text { the ending and } \\
\text { beginning times. }\end{array}$ & 3 & 14 & 84 & 174 & 266 & 1.73 \\
\hline $\begin{array}{l}\text { 19. I like to know how } \\
\text { long it will take before } \\
\text { i begin. }\end{array}$ & 7 & 19 & 104 & 196 & 216 & 1.90 \\
\hline $\begin{array}{l}\text { 20. I plan each and } \\
\text { every day. }\end{array}$ & 17 & 91 & 164 & 168 & 101 & 2.54 \\
\hline $\begin{array}{l}\text { 21. I believe that } \\
\text { people should not } \\
\text { waste their time. }\end{array}$ & 1 & 8 & 50 & 99 & 279 & 1.51 \\
\hline $\begin{array}{l}\text { Long term orientation - } \\
\text { global response }\end{array}$ & & 1.93 & & & & \\
\hline $\begin{array}{l}\text { Short term orientation - } \\
\text { global response }\end{array}$ & & 2.22 & & & & \\
\hline $\begin{array}{l}\text { General score for a scale } \\
\text { form } 1-100\end{array}$ & & 53 & & & & \\
\hline
\end{tabular}

* questions written in bold are indicative of long-term orientation, while the rest are specific to short-term orientation

Level of education

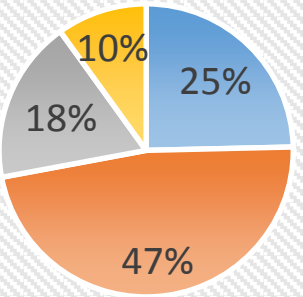

Figure 1. Level of education

Source: contribution of authors

$\mathrm{PhD}$

\section{Gender}

- High School

Bachelor

- Master or

$69 \%$

Figure 2. Gender

Source: contribution of authors 


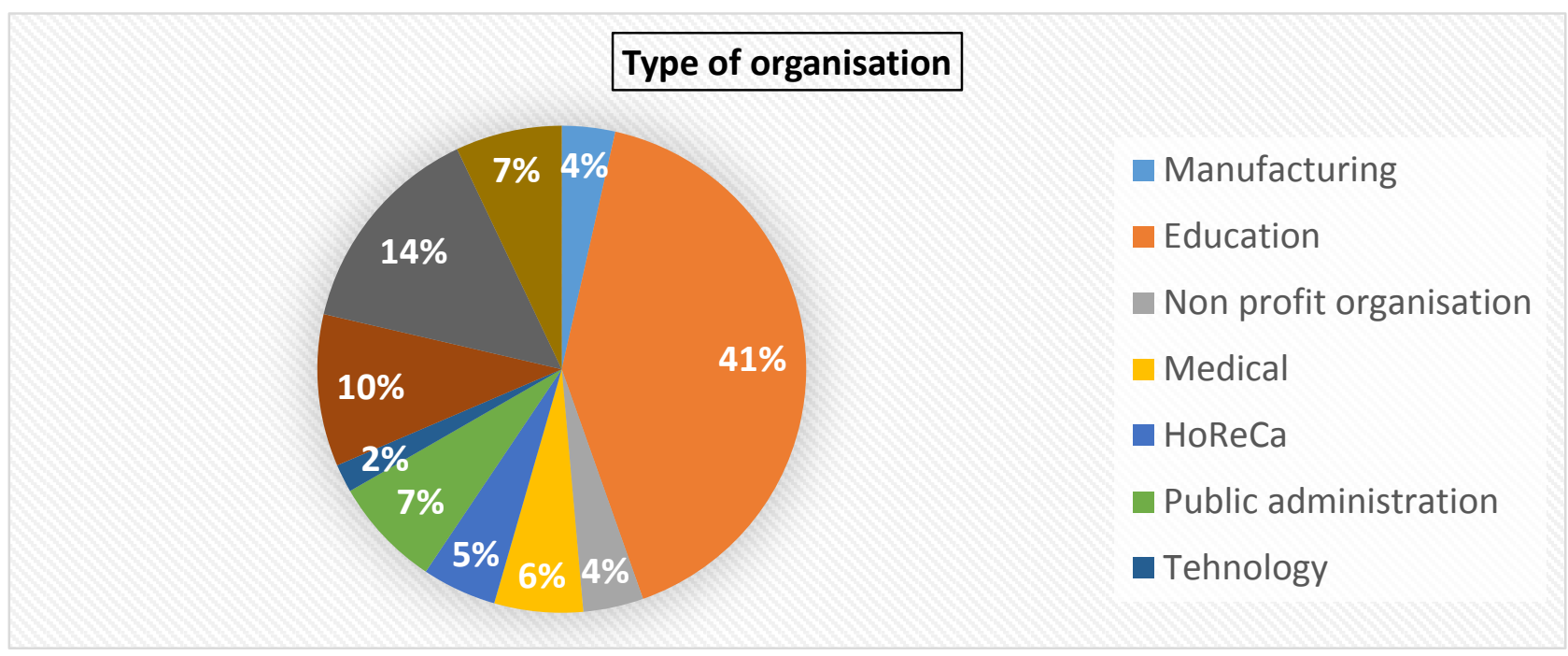

Figure 3. Type of organisation

Source: contribution of authors

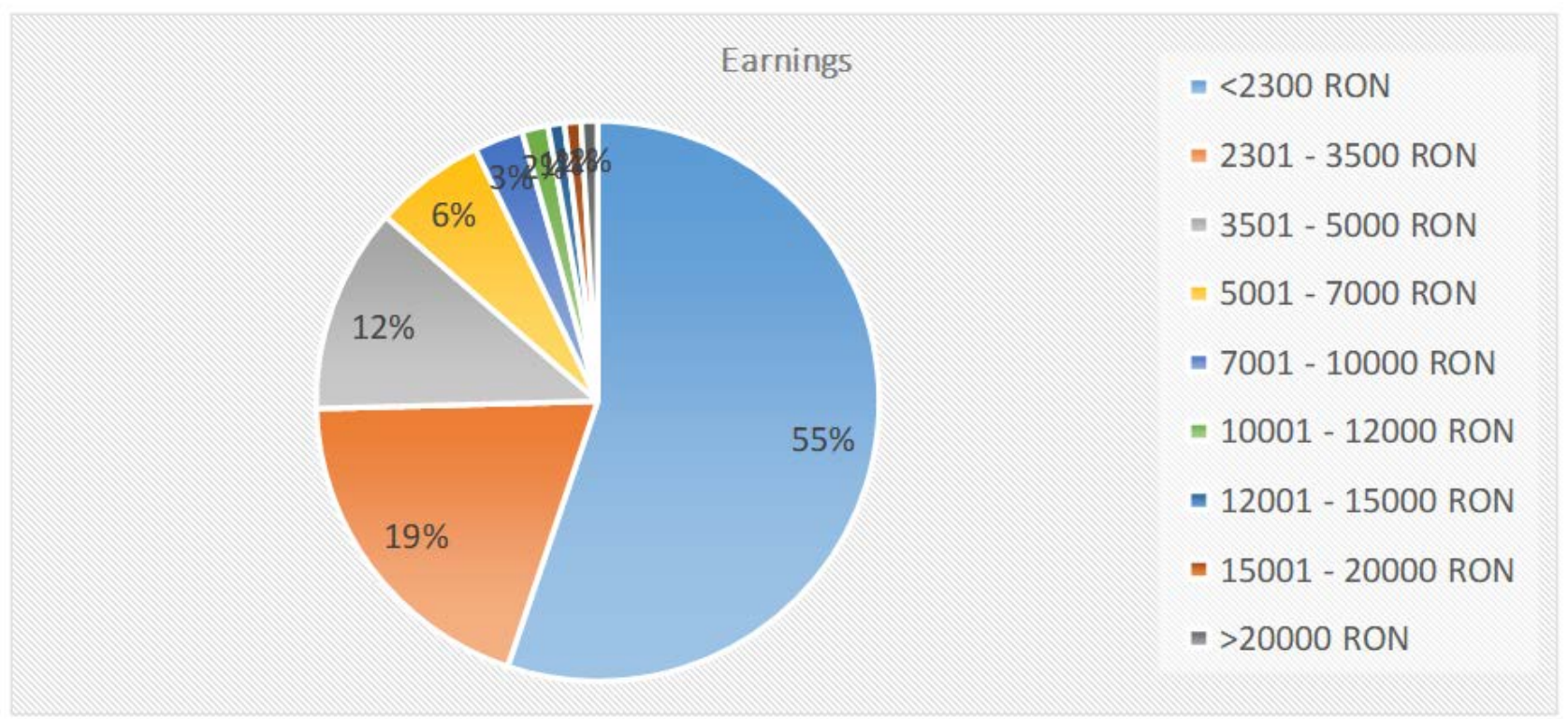

Figure 4. Earnings

Source: contribution of authors

In processing the answers in order to calculate the long-term or short-term orientation score, we proceeded as follows:

1. We grouped the short-term orientation (STO) and long-term orientation (LTO) questions and their answers. In Table 1., LTO questions are written in bold.

2. We calculated the average score of the answers to each question, multiplying the number of answers for each level of the Likert scale by the numerical value corresponding to that level and dividing by the total number of respondents. We calculated the average of the averages obtained from the LTO questions and separately for the STO questions, by dividing their amount by the corresponding number of questions.

3. Thus we obtained a score for LTO, respectively STO.

4. In order to obtain an overall score comparable to that estimated by Hofstede, we used the formula for calculating the long-term orientation in the 2013 VSM Manual, given below: Long-term orientation index $=40($ m13 - m 14) $+25(m 19-m 22)+$ Clto, 
where $\mathrm{m} 13, \mathrm{~m} 14, \mathrm{~m} 19$ and $\mathrm{m} 22$, represent the average of the answers to questions $13,14,19$ and 22, from Hofstede's VSM 2013 questionnaire, and Clto $=$ the constant that adjusts the score so that the results can be compared.

5. This meant regrouping the questions in our questionnaire, as well as the related answers, around the 4 questions in the 2013 VSM, so that we could apply the formula.

It is noteworthy that the long-term orientation dimension was studied by means of only two questions in the 1994 VSM questionnaire and four questions in Hofstede's VSM 2013.

Our questionnaire addressed a much larger number, 21 questions, to highlight the preferences of Romanians for the values on the side of the positive pole, respectively the negative one associated with this dimension, which can increase the validity of the results. For example, in order to question the Romanians' preferences for the value of persistence, the questionnaire provided six questions, numbered 2, 9, 12, 13, 14 and 16.

The general score obtained, respectively that of 53, according to the formula in VSM 2013, shows an intermediate position between short-term orientation and long-term orientation, with a slight bias towards long-term orientation. In fact, this result is very close to the value of 52, estimated by Geert Hofstede for Romania.

Next, we set out to test, using the Chi-square test, the existence of a correlation between the respondents' level of education and their income level and the long-term versus short-term orientation. We formulated the following two hypotheses:

H1: The level of education influences the degree of long-term orientation

H2: The level of revenue influences the degree of long-term orientation

To test these hypotheses, we used SPSS software, used in quantitative research.

As can be seen in Table 3, hypothesis $\mathrm{H} 1$ is validated because the value of the asymptotic significance, respectively 0.019 , is below the allowed significance threshold of 0.05 . Thus, it is demonstrated that the level of education influences the cultural orientation. The higher the level of education, the greater the tendency to have a longer-term orientation. On the other hand, individuals with a lower level of education have shorter-term orientation.

Table 2. Study level * Long-term orientation Cross-tabulation

\begin{tabular}{|ll|r|r|r|r|r|}
\hline & & \multicolumn{4}{|c|}{ Long-term orientation } & \multirow{2}{*}{ Total } \\
\cline { 3 - 6 } & & Disagree & Neutral & Agree & $\begin{array}{c}\text { Strongly } \\
\text { agree }\end{array}$ & \\
\hline Study & High school & 0 & 16 & 93 & 16 & 125 \\
level & Bachelor & 1 & 28 & 137 & 35 & 201 \\
& Master or & & & 74 & 11 & 98 \\
& PhD & 0 & 13 & 7 & 3 & 13 \\
& Others & 1 & 1 & 8 & 65 & 437 \\
\hline
\end{tabular}

Source: contribution of authors 
Table 3. Chi-Square Tests

\begin{tabular}{|l|r|r|r|}
\hline & \multicolumn{1}{|c|}{ Value } & df & \multicolumn{2}{|c|}{$\begin{array}{c}\text { Asymptotic } \\
\text { Significance (2-sided) }\end{array}$} \\
\hline Pearson Chi-Square & $19.847^{\mathrm{a}}$ & 9 & .019 \\
Likelihood Ratio & 9.793 & 9 & .368 \\
Linear-by-Linear & .048 & 1 & .826 \\
Association & 437 & & \\
N of Valid Cases & & \\
\hline
\end{tabular}

a. 6 cells (37.5\%) have expected count less than 5. The minimum expected count is .06.

Source: contribution of authors

However, with regard to the second hypothesis, this is not confirmed. Thus, the level of income does not influence long-term orientation.

Table 4. Income level * Long-term orientation Cross-tabulation

\begin{tabular}{|ll|r|r|r|r|r|}
\hline & & \multicolumn{3}{|c|}{ Long-term orientation } & \multirow{2}{*}{ Total } \\
\cline { 3 - 7 } & & Disagree & Neutral & Agree & $\begin{array}{c}\text { Strongly } \\
\text { agree }\end{array}$ & \\
\hline Income & Under 2300 lei & 1 & 28 & 183 & 34 & 246 \\
level $\quad$ Between 2301 and 3500 lei & 1 & 10 & 54 & 16 & 81 \\
& Between 3501 and 5000 lei & 0 & 8 & 37 & 5 & 50 \\
& Between 5001 and 7000 lei & 0 & 5 & 21 & 3 & 29 \\
& Between 7001 and 10000 lei & 0 & 2 & 6 & 3 & 11 \\
& Between 10001 and 12000 lei & 0 & 2 & 3 & 0 & 5 \\
& Between 12001 and 15000 lei & 0 & 1 & 3 & 1 & 5 \\
Between 15001 and 20000 lei & 0 & 1 & 3 & 1 & 5 \\
Total & Above 20000 lei & 0 & 1 & 2 & 2 & 5 \\
& & 2 & 58 & 312 & 65 & 437 \\
\hline
\end{tabular}

Source: contribution of authors

Table 5. Chi-Square Tests

\begin{tabular}{|l|r|r|r|}
\hline & \multicolumn{1}{|c|}{ Value } & df & \multicolumn{2}{|c|}{$\begin{array}{c}\text { Asymptotic } \\
\text { Significance (2-sided) }\end{array}$} \\
\hline Pearson Chi-Square & $15.200^{\mathrm{a}}$ & 24 & .915 \\
Likelihood Ratio & 14.353 & 24 & .938 \\
Linear-by-Linear & .238 & 1 & .626 \\
Association & 437 & & \\
N of Valid Cases & & \\
\hline
\end{tabular}

a. 25 cells (69.4\%) have expected count less than 5 . The minimum expected count is .02.

Source: contribution of authors 


\section{INTERPRETING THE RESULTS}

The long-term orientation index resulting from our calculation is 53, which is slightly above the value estimated by Geert Hofstede (52). We must mention that we reached this score by applying the formula corresponding to this dimension from the 2013 VSM Manual, but starting from the answers to a questionnaire that is different from the one used by Hofstede. However, due to the nature of the questions asked, our questionnaire addressed the same values associated with the LTO dimension, at its two opposing poles. Thus, the 21 questions in our questionnaire were grouped around four values: temperance and persistence for LTO, and respect for tradition and reciprocity in greetings, favors, gifts, for STO.

Below, we will selectively comment on the answers to the most relevant questions relating to the four cultural values mentioned above:

\section{Temperance}

- When asked if they "save money regularly for emergencies or future expenses", 67\% of respondents answered with "agreement" and "full agreement". As can be seen, the answers to this question indicate the tendency of Romanians to save, so a long-term orientation. However, a study by the NBR shows that at the end of 2015, 66\% of individual depositors in banks held only $1 \%$ of total deposits, their accounts having amounts of only up to 1000 lei/depositor, which is not indicative of consistent, purposeful savings (Georgescu, F., 2017).

- To the question "I don't mind giving up fun now in order to be more successful in the future”, 58.30\% answered with "total disagreement” and “disagreement”, and 24\% being undecided. From these answers we can deduce the great importance that Romanians give to free time, a value associated with short-term orientation. Given that a large majority of respondents were students of universities and high schools, we can recognize here a characteristic feature of Generations Y and Z.

- Regarding question number 15, "If I want to buy something expensive and I don't have money, I will buy it anyway", the overwhelming majority of respondents stated that they would not "spend the money they don't have" for a good that they want. However, the data of the National Bank of Romania indicate that, in 2015, in Romania there were 908,475 borrowers, and the number of loans was 1,508,535. Thus, although the answers to this question would suggest a long-term orientation, the statistics suggest the opposite.

\section{Persistence}

- When asked if they were "looking for future investment opportunities", the cumulative percentage of the answer choices "agreement" and "total agreement" was $61 \%$. We could interpret these answers as being in line with the entrepreneurial inclinations of the young generation.

- When asked if they have long-term goals, we again have a considerable percentage of positive answers. The cumulative percentage for the answer choices "agreement" and "total agreement" was $80.1 \%$. Should we be optimistic about Romania's future?

- $\quad 81.46 \%$ of respondents said that "they work hard to be successful in the future". However, persistence in work and work under pressure appear in the category of "peripheral values" and not of "central values" of Romanians, according to Dorin Bodea's study on the values of Romanian employees (Bodea, 2013).

\section{Respect for traditions}

- In Question 8, if 'respect for tradition is important', 61\% think it is 'important' and 'very important', and 26.42 are undecided.

- "Traditions and family heritage" are "important" and "very important" for $61.65 \%$ of respondents. 
- These results reconfirm the psychological characteristics of Romanians, pointed out in many other studies, emphasizing the presence of respect for traditions, customs and history.

- From here, we can deduce a short-term rather than a long-term orientation, respect for tradition being associated with the negative pole of the LTO dimension. Often, however, traditions and old practices, especially in the professional sphere, can lead to resistance to change and innovation.

\section{Reciprocity to greetings, favors and gifts}

- The importance of this value was tested by question 5: "responding to congratulations, favors and gifts is important to me". 76.33\% said it was "important" and "very important". In D. Bodea's (2013) study, "friendship" and "quality relationships", which in their sense also include reciprocity in favors and gifts, are included in the category of "semi-central values", close to the central ones. This value being associated with the short-term orientation, we deduce the Romanians' preference for not too distant perspectives.

Given that about $80 \%$ of our respondents come from the historical region of Moldova, as well as the fact that Romania and the Republic of Moldova have many common cultural values, we also took a look at the long-term orientation index in the neighboring country, as already mentioned in the section „Previous research” (Popov, 2019). This index is 36 in the case of the Republic of Moldova, but it differs depending on the age of the respondents. The study authors calculated this index for two age groups, young people between 18 and 35 years old, and people over 35 years old. The differences between the two scores are significant, being 42 in the case of respondents up to 35 years old and 25 in the case of those over 35 years old. This shows that a succession of generations brings with it, if not the profound change of culture, at least its modeling in accordance with the new software of the mind of new generations.

\section{RESEARCH LIMITATIONS}

It is important to note that the LTO score we obtained (53) would have had a different value if we had calculated it using only four questions from the questionnaire, one for each cultural value questioned. However, we consider that the higher number of questions asked is more conducive of obtaining better result validation.

Another limitation of our research was omitting to take into account the age of the respondents.

\section{ACKNOWLEDGMENT}

„This work is supported by the project ANTREPRENORDOC, in the framework of Human Resources Development Operational Programme 2014-2020, financed from the European Social Fund under the contract number 36355/23.05.2019 HRD OP /380/6/13 - SMIS Code: 123847.”

\section{REFERENCES}

Bodea, D. (2013). Valorile angajaților români. București: Editura Result.

Gănescu, C., Gangone, A. \& Asandei, M. (2014). Evaluarea sistemului cultural naţional asupra comportamentului organizaţional responsabil faţă de consumatori: o aplicare a modelului cultural al lui Geert Hofstede, Amfiteatru Economic, XVI(35), Februarie, 321-337.

Georgescu, F. (2017). Creșterea economică, dezvoltarea României și reducerea sărăciei, Studiu al BNR. Retrieved August 27, 2020, from https://www.bnr.ro/Situa\%C8\%9Bia-crediteloracordate-persoanelor-fizice-13212-Mobile.aspx.

Kahn, H (1979). World Economic Development: 1979 and Beyond. Londra: Croom Helm.

Hofstede, G., Hofstede, G., J. \& Minkov, M. (2012). Culturi și organizații. Softul mental. București: Editura Humanitas. 
Luca, A. (2016). Un studiu despre valorile şi comportamentul românesc din perspectiva dimensiunilor culturale dupa metoda lui Geert Hofstede. Studia Universitatis Babes-Bolyai Sociologia 61(2), December, 167-171. Retrieved July 15, 2020, from https://www.researchgate.net/publication/323725094_On_studiu_despre_valorile_si_comporta mentul_romanesc_din_perspectiva_dimensiunilor_culturale_dupa_metoda_lui_geert_hofstede_ study_about_romanian_values_and_behaviour_from_the_perspective_of_cultural_d

Mihut, I. \& Lungescu, D. (2006). Dimensiuni culturale în managementul românesc, Management \& Marketing Journal, (1), 5-26.

Popov, S., Mendes, T., Toma, C., Mihăilă, A.-M., Barbarov, I., Vozian, M. et al. (2020). Analiza culturală și psihologică a societății din Republica Moldova. Retrived July 15, 2020, from https://www.researchgate.net/publication/338374501_Analiza_culturala_si_psihologica_a_soci etatii_din_Republica_Moldova_conform_modelului_teoretic_a_lui_Geert_Hofstede.

Rusu, S., Isac, F., L. \& Curteanu, R. (2015). Cultural Dimensions in Romanian Management. Lucrări Științifice Management Agricol, 17(2), 136-140. 